\title{
Just like in Germany, only better? Old-age care facilities in Poland for people from Germany and the question of legitimacy
}

\author{
Sonja Großmann ${ }^{1}$ and Cornelia Schweppe ${ }^{1 \star}$ \\ ${ }^{1}$ Institute of Education, Johannes Gutenberg-University Mainz, Germany \\ ${ }^{*}$ Corresponding author. Email: schweppc@uni-mainz.de
}

(Accepted 11 September 2018; first published online 16 October 2018)

\begin{abstract}
This article deals with old-age care facilities in Poland which are aimed at people from Germany. These facilities emerge against the background of severe criticism of old-age care facilities in Germany. The media projects a widespread use of these facilities, claiming this is mainly due to the lower costs as compared to Germany. Against the backdrop of normative discussions about old-age care in Germany, doubts about a widespread use of facilities abroad may arise. Indeed, we will show that in quantitative terms, the facilities in Poland are a marginal phenomenon. Drawing on neo-institutional organisation theories, we demonstrate that the facilities face legitimisation challenges that consist of being able to align with the socially shared values and norms of old-age care in Germany to position themselves as a legitimate option. We analyse whether and how the facilities deal with these challenges. We particularly focus on the only facility we found that has a substantial number of residents from Germany. We show how the facility takes on the legitimation challenge by its motto 'Just like in Germany - only better', while other facilities position themselves as 'low-cost facilities for people from Germany'. The low take-up of the latter indicates that low prices alone do not attract a substantial number of residents from Germany into the facilities.
\end{abstract}

Keywords: old age; ageing; old-age care; international care migration; Poland; transnational ageing; legitimacy; 'granny export'

\section{Introduction}

Old-age care is one of the key challenges of many European and North American countries, a challenge that is often referred to as the 'old-age care crisis'. Developments in response to this crisis that cross national borders can increasingly be observed. In research to date, particular attention has been drawn to the increasing use of migrant care workers for the care of older people in private households. In many central and southern European countries, as well as in North America, these arrangements have become an important pillar of, and often an indispensable option in, old-age care. This also applies to Germany. This is a widely used option, 
as reflected in the high number of migrant care workers currently in Germany. Estimated numbers vary considerably and go up to a maximum of 300,000 migrant workers (Arend, 2017).

In parallel, another more recent transborder development can also be observed, namely the establishment of old-age care facilities in other countries, catering to specific national groups of people in need of care. Toyota and colleagues pointed to this development in South-East Asia (Toyota and Xiang, 2012; Toyota and Thang, 2017). Since about ten years ago, this development has also been observed for older people in need of care from Germany. Most of these facilities have been established in South-East Asia (mainly Thailand) and Eastern Europe. To date, these facilities have attracted scant academic attention. The project 'Moving Old-age Care Abroad' addresses this gap by analysing the spread of these facilities in Thailand and Poland, the arguments of these facilities to present themselves as an attractive alternative to old-age care facilities in Germany, people's motives for choosing these facilities, and the living and care conditions the facilities offer (for Thailand: Horn et al., 2016; Bender et al., 2017).

This article presents partial results of the study of old-age care facilities in Poland that are aimed at people from Germany. In particular, it will address the question of how widespread is the use of these facilities for people from Germany, as well as the arguments and strategies adopted by the facilities in order to be considered a legitimate option by people from Germany.

The media projects a widespread use of these facilities, claiming this is mainly due to the much lower costs as compared to Germany. However, against the backdrop of normative discussions about old-age care in Germany, doubts about a widespread use of facilities abroad may arise. In fact, we will show that in quantitative terms, the facilities in Poland are a rather marginal phenomenon. Using neo-institutional organisation theories, we demonstrate that the facilities face legitimisation challenges which consist of being able to align with the socially shared values, norms or ideas of old-age care in Germany in order to position themselves as a legitimate option. Accordingly, we will analyse whether and how the facilities deal with these challenges.

The article is structured as follows: after presenting our theoretical framework, we will outline current criticism of old-age care facilities in Germany. This criticism is the central backdrop for questions of the acceptance or rejection of the facilities in Poland as well as a crucial frame of reference for the facilities positioning themselves as a legitimate option. We will then present the empirical results of our study, first with reference to the quantitative use of the facilities in Poland and second to the arguments and strategies the facilities develop to position themselves as a legitimate option for people from Germany. We will then turn our attention particularly to the only facility in Poland we found in our study with a substantial number of older residents from Germany; this facility has even been expanding due to increasing demand.

\section{'Is this the right thing to do?' Legitimisation challenges and neo-organisational theories}

Old-age care facilities abroad pick up on the severe criticisms of care facilities in Germany and attempt to project themselves as appropriate alternatives. The high 
costs of old-age care facilities in Germany and the much lower fees of the facilities in Poland help to make the latter appear as an attractive alternative. In the widespread media coverage of these facilities under the tag line of 'the granny export', the lower prices are considered to be the prime reason of a supposed mass relocation of older people in need of care from Germany to Poland. However, against the backdrop of normative expectations of old-age care in Germany, there are reasons to question this supposed widespread use. For example, there is a public discourse which criticises the use of these low-cost facilities based on arguments that people in need of care would be deported or that the low cost would be taken advantage of by relatives with financial interests (see below). In particular, the facilities in Poland challenge the prominent principle of 'ageing in place' which guides old-age care in Germany. The normative discussion about 'good care' in Germany is closely entwined with this principle of staying in familiar environments (Engelmann et al., 2013). That also applies to out-of-home care. If the move into an old-age care facility cannot be avoided, the chosen care facility should be located geographically close to the care recipient's familiar environment (Mischke et al., 2015). Thus, the principle of 'ageing in place' locates 'good care' for older people within the local and - in the broadest sense - national context. The significance of this principle is also reflected in studies which show that placing a relative close to his or her familiar environment is a special seal of quality when choosing a care facility (Mischke et al., 2015). Facilities in Poland challenge this principle. They decouple out-of-home care from a familiar environment and the German national context and require old-age migration for the purpose of care. Thus, old-age care facilities in Poland do not directly align with the socially shared values, norms or ideas expressed in this guiding principle about what constitutes desirable care for old people in Germany.

In neo-institutional organisation theories, such an alignment is considered to be crucial for the legitimacy of organisations. Suchman defines it as follows: 'Legitimacy [of an organization, the authors] is a generalised perception or assumption that the actions of an entity are desirable, proper, or appropriate within some socially constructed systems of norms, values, beliefs or definitions' (Suchman, emphasis in original, cited in Walgenbach and Meyer, 2008: 64). Legitimacy is considered to be one of the key criteria for ensuring the survival of organisations (Walgenbach and Meyer, 2008). The quote indicates that legitimacy is less something that an organisation possesses and more something that it gets given: 'Legitimacy is a relationship with an audience rather than being a possession of the organization' (Suchman, cited in Walgenbach and Meyer, 2008: 65). Accordingly, legitimacy is always linked to a specific field or reference group. This reference group is the resonance space (Rehberg, cited in Walgenbach and Meyer, 2008: 65), that 'assess[es] the adequacy of an actor's activities'. It gives the organisation legitimacy. In principle, an organisation is considered to be legitimate if, from the perspective of this group, it meets the expectations placed on it (Rehberg, cited in Walgenbach and Meyer, 2008: 65).

Care facilities in Poland are aimed at the market in Germany. If they want to exist and secure their survival in this market, they need to secure the use (i.e. demand) by people from Germany. Therefore, old people in need of care in Germany and their relatives can be regarded as an essential reference group of 
the facilities in Poland. However, given that the facilities in Poland do not directly align with the normative expectations of 'good care' in Germany, from the perspective of this reference group, the question may rise, when looking at possibly using such a facility: '[Is this] the right thing to do?' (Suchman, 1995: 579). According to Suchman (1995: 579), the responses to this question 'usually reflect beliefs about whether the activity effectively promotes societal welfare, as defined by the audience's socially construed value system'.

Against this background, the question arises of how widespread the use of oldage care facilities in Poland really is. In addition, if the facilities want to exist on the German market, it can be assumed that they are faced with challenges to being considered as a legitimate option. Due to the fact that old-age care abroad is a relatively new form of organisation, the facilities in Poland cannot resort to any correspondent models. Accordingly, we analyse whether and how the facilities face this challenge and what arguments and strategies the old-age care facilities in Poland develop to project themselves as a legitimate option.

We begin by looking at the current criticism of old-age care facilities in Germany. This criticism provides the background against which questions of acceptance and the social construction of legitimacy of facilities in Poland unfold.

\section{Criticism of old-age care facilities in Germany}

A central point of criticism of old-age care facilities in Germany is related to financial factors. The private-to-public ratio expenditure for long-term care in Germany is among the highest in the European Union (EU) (Lipszy et al., 2012). According to German law, it is possible to tap into or use up the personal property of people requiring care (e.g. their private home) or their children's income to make up for a cashflow shortfall in financing care.

The considerable cost burden in Germany is reflected in the large number of people who are unable to cover the costs of old-age care facilities and require supplemental financial support from the state. Utilisation of Hilfe zur Pflege (supplemental public care assistance) has been increasing since 1995. During 2015, there were 450,674 recipients, of whom approximately 72 per cent lived in old-age care facilities (Statistisches Bundesamt, 2015). The cost problem is also reflected in opinion surveys.

Apart from the financial aspect, the reluctance to use old-age care facilities in Germany can also be explained by widespread doubts about their quality. Fierce criticism is levelled at the fact that organisational rationalities outweigh individuality, ensuring that institutional procedures run smoothly but leaving facilities unable to satisfy individual needs and necessities. This often goes along with a lack of resident participation, the right for residents to exert their free will and maintain their own temporal rhythms and opportunities for action, a lack of private spaces and single rooms, as well as the use of restraints (Schneekloth and Wahl, 2009). Critics also refer to the dominance of the medical paradigm in care. Because the benefit system recognises the need for care as resulting only from illness and disability, both care at home as well as out-of-home care are mainly related to somatic aspects and hygiene. Accordingly, social or emotional aspects often cannot be taken into account. Strict stipulations for the services that can be billed, according to 
which activities such as feeding or bathing are calculated on a per-minute basis, are a particularly striking illustration of the standardisation of care (Behr, 2015).

A central structural problem of old-age care facilities in Germany is the precarious staff situation. In addition to a significant labour shortage, ${ }^{1}$ the precarious staff situation is influenced by the working conditions: low pay accompanied by heavy workloads and rising demands, lack of social recognition and fast-paced schedules, with little chance to satisfy people's individual needs for care, often resulting in relationships that work according to principles of rationality and a high staff turnover.

Finally, problems of negligence, violence and the (medically unjustified) use of sedatives to immobilise residents labelled 'aggressive' or 'difficult' have also been identified in research (Grassberger and Püschel, 2013: 250). For years, these issues have also attracted media attention to this pervasive problem in German old-age care facilities, under headlines such as 'Forcibly sedated' (Kunze, 2015, translation by the authors).

These structural problems and the negative image of old-age care facilities in Germany are important reasons why individuals and families look for alternative solutions. The search for alternatives abroad, in turn, is inextricably linked to the gradual opening up of the German social security system, allowing people to receive certain social benefits while residing in another country. In the case of Poland, this especially refers to the transfer of old-age pensions received from the German pension insurance and benefits from the long-term care and health insurance. In addition, the EU right to freedom of movement, which allows relocation within the EU with little bureaucratic effort, e.g. no obligation to apply for a residence permit (European Union, 2009: part 2, article 21 (1)), make moves to Poland relatively easy.

\section{Facilities in Poland as an attractive option: the lower prices}

Old-age care facilities in Poland for people from Germany take up these criticisms. They especially take up the high cost burden in Germany. The facilities in Poland offer attractive cost alternatives, with monthly costs ranging from $€ 1,000$ to $€ 1,500$. By comparison, depending on requirements, the cost in Germany in 2015 was between $€ 2,170$ and $€ 3,165$ per month plus accommodation and food (Statistisches Bundesamt, 2017). The significant differences in the cost of old-age care between Poland and Germany are due to the considerably lower wages and costs of living in Poland. Much lower costs constitute a key element in the Polish facilities' advertising strategies.

When old-age care facilities in Eastern Europe, and particularly in Poland, for people from Germany have received substantial media attention, the reasonable prices are cited as the prime reason for care migration to Poland. The media message implies that due to this reason there is a massive shift of old-age care from Germany to Poland, as indicated by headlines such as 'Exporting granny: How Germany shunts off its old people to Eastern Europe' (Focus Online, 2014, translation by the authors) or 'Germany leads the world in granny exports' (Posener, 2014, translation by the authors). A quick internet search for care options for people from Germany conveys the same impression of an extensive spread of old-age care facilities in Eastern Europe that target older people from Germany. There are many 
internet portals for facilities located in Poland or Eastern Europe that advertise to people from Germany (e.g. Carefinder or Pflege-in-Polen.net (Care-giving in Poland)), along with websites of specific individual facilities located in Poland. The internet site Wohnen im Alter (Senior Living) alone, a widely used portal for care options for older Germans, lists 26 old-age care facilities in Poland catering to people from Germany (May 2017). Although some media voices here and there have begun to question the extent of 'granny exports' (Mihm, 2013; Kahlweit, 2016), they seem to have had little impact on the notion of a massive spread and use of facilities in Poland.

\section{Scepticism: the foreign country and doubts about quality care}

In stark contrast to this assumption of a widespread use of the facilities in Poland are opinion polls about attitudes in Germany about placing a person in an old-age care facility abroad, which show a widespread rejection and scepticism towards oldage care abroad. In a representative survey, Emnid - a German opinion research institute - found that 23 per cent of Germans reject placing a relative in need of care in an old-age care facility, while 85 per cent of Germans reject placing a relative in need of care in a care facility abroad (Konpress and Emnid, 2013). In the same study, only 12 per cent of respondents could picture placing a relative in a care facility abroad under certain circumstances, compared with 57 per cent who could imagine placing a relative in a care facility in Germany under certain circumstances. While these numbers show the general reluctance to place a relative in a care facility, this rejection is especially high in the case of placing them in a care facility abroad. Only for 3 per cent of Germans is this kind of move of their relative to a foreign country an unqualified option, compared with 17 per cent when it comes to placement in a care facility in Germany. When people were asked if they could imagine opting for a care facility abroad in case they themselves are in need of care, the numbers were only slightly higher (Konpress and Emnid, 2013).

The same study asks about the reasons why people reject the option of choosing a care facility for a relative abroad. The most cited reason ( $89 \%$ of respondents) is because of the wish to keep relatives geographically close. This reflects the importance of the above-mentioned principle of 'ageing in place'. Geographical distance, which goes hand in hand with placing a relative in a care facility abroad, seems to be a significant obstacle. However, geographical distance is not the only reason why a foreign country seems to be a problem. A total of 72 per cent reject care abroad because they expect language barriers and problems in communicating; 71 per cent because they consider it difficult for old people to deal with a different culture; and 56 per cent because they are afraid that medical standards are not as high as in Germany. Geographical distance, cultural and linguistic differences, and a lack of confidence in other countries' medical standards are three central arguments which make a foreign country a problem when choosing an old-age care facility. This shows that it is the foreign country and expected difficulties due to geographical distance as well as cultural and linguistic differences that lead to the rejection of care outside Germany. Ultimately, it emphasises the importance of the principle of 'ageing in place', which places 'good care' in the familiar environment and in the broadest sense in the national context. 
The way old-age care facilities in East Europe are presented in the German media reflects further arguments as to why their use might be rejected. References to the discourse on 'deporting older people' figure prominently. The 'deportation argument' is closely related to the low costs of old-age care facilities in Poland and, as a result, is criticised. For example, a press release for a symposium on old-age care in Germany says: "The "deportation" of German patients suffering from dementia abroad was highly criticised at the symposium of the state parliament in North Rhine-Westphalia: this kind of "granny export" on account of costs would be inhumane' (Westfälische Nachrichten, 2012, translation by the authors). Financial reasons are presented as illegitimate justifications. This argument is emphasised by connoting care in Poland as 'discount care' (Focus Online, 2012, translation by the authors). Low-cost care in old-age care facilities in Germany has the reputation of qualitatively substandard care, which is implicitly also contained in the notion of 'discount care'. In this line of argument, 'discount care' and 'good care' are mutually exclusive. Lastly, the term 'granny export' reifies 'Grandma' and, in line with the notion of 'export' in economics, is linked to economic interests. Accordingly, it comes as no surprise that the mass media at times describes the use of old-age care abroad as dumping, inhumane and even as a 'forced disposal of old people' (Prantl, 2012, translation by the authors).

Given the discrepancy between the supposedly widespread use of care facilities in Poland, on the one hand, and the high rejection revealed by opinion polls and the criticism implied in the German media presentation of old-age care in Eastern Europe, on the other, in the following we will ask how widespread this so-called 'mass phenomenon' actually is. There are currently no available figures for older people from Germany living in care facilities in Poland.

\section{Methodological approach}

Our study is based on the following empirical approach: to gauge the spread of oldage care facilities targeted at people from Germany, we started with an internet search using the search parameter of facilities in Poland whose website was accessible in German in addition to Polish. We found 32 websites that fit our criteria. To gain an initial insight into the character of these facilities, we explored these websites to find out about their costs, location, size, personnel, and their care and other offerings. Next, we attempted to contact the 32 facilities we found in our internet search, first by email, and in case of no response, by phone, to explore the possibility of visiting them on site. We also asked about the number of persons from Germany they currently hosted.

On the basis of the results of this first phase, we selected nine facilities for further exploration (see explanation below). We visited these facilities in 2015. During our field work in Poland we conducted narrative-generating guided interviews with the facilities' managers or care managers. We started with a narration-generating stimulus stating our interests in care facilities in Poland targeted at people from Germany and explaining that we would like to learn about the development of the respective facility and everyday life and care delivery there. Depending on the respective information given, we added questions about the problems and challenges they encounter, as well as about the qualifications and numbers of staff, and 
the residents' biographical backgrounds. We also asked about their experiences with regard to the decision-making process of placing a person from Germany in the respective facility, and the way they counter possible objections and/or explain why their facility might not have attracted a substantial number of residents. With one exception, all of the interviewees additionally showed us the premises of the facilities. The interviews were mostly conducted in German, and in some instances an interpreter was involved to translate from Polish to German or English and vice versa. The interviews ranged from 15 minutes (in the case of one spontaneous visit without an official appointment) up to multiple hours stretched over two days.

Data analysis followed an inductive exploratory approach which was guided by grounded theory methodology (Strauss and Corbin, 1996). Based on the transcriptions of the interviews, they were coded and analysed line by line to identify potential key themes. Following the constant comparative method (Strauss and Corbin, 1996), we continuously compared the themes emerging with one another and explored theoretical ideas and concepts. This way ideas and concepts were refined, while new ones were also generated. As an additional data source, in selected cases, such as in the 'At the Riverside' facility, which we will turn to below, we also included an analysis of their websites. This analysis followed the same procedure of analysis as the one of the interviews. The results of the website and the interview analysis were then related to each other to further deepen our analysis and to refine the emerging theoretical categories.

\section{Big supply, little demand - the 'granny export' as media hype}

The first result of the study came out of our attempt to contact the facilities we found in our internet search. Out of the 32 facilities we found, ten facilities were unreachable despite repeated attempts to contact them by email and phone; two of them took down their websites that same year (2015). Of the remaining 22 facilities, two indicated that their facilities were not open yet due to organisational difficulties; four facilities were actually hotels which were or had been planned to be converted into care facilities. The reason given for the (so far) unrealised plans was insufficient demand by people from Germany. In the case of three facilities, our contact broke down due to the Polish-German/English language barriers. The remaining four facilities were only occupied by people from Poland. Ultimately, we found nine facilities that were operational and which indicated that at least some of the residents were from Germany. On site we then found out that only four of the facilities actually had German residents. The remaining five facilities had not been able to recruit residents from Germany. In one case, it was not a care facility but a hotel.

As a result of our field trip and the phone survey, altogether we found 110 residents from Germany in these facilities. Even though this is a rough estimate of how many people from Germany were residing in the facilities in Poland in 2015, the numbers show that there is not a massive shift in old-age care from Germany to Poland. On closer examination, many of the offerings turn out not to exist; as for the existing offerings, they have encountered little demand from their target market. In our interviews, the facility managers raised the subject of lack of demand 
from Germany repeatedly and without being prompted. Almost without exception, they were puzzled as to why they could not attract more people.

\section{The old-age care facility 'At the Riverside'}

One facility stands out from our quantitative analysis: the old-age care facility 'At the Riverside' established itself as having a substantial number of older residents from Germany. While the other facilities housed five, six, ten and 13 residents, respectively, from Germany in addition to residents from Poland, the facility 'At the Riverside' housed people from Germany exclusively, with a total of 59 residents, and due to high demand it expanded the facility to offer places for a total of 80 residents. Based on the analysis of our interviews with the facility care manager and of the facility website, ${ }^{2}$ we will show in the following which strategies it follows to promote itself as a legitimate old-age care option for people from Germany. In this analysis, we will include findings from the other facilities to point out corresponding differences.

\section{The management team}

The facility 'At the Riverside' has a German name and was established in 2013. It is located about $300 \mathrm{~km}$ away from the German-Polish border. The management team consists of two managers plus the care manager. The care manager comes from Germany and worked there in old-age care facilities as a trained geriatric nurse until she was employed for this position in the facility in Poland. The general manager, a trained business consultant, lives in Germany. He can be reached through a German telephone number published on the facility's website. He and the care manager are the primary contact persons for people in need of care and their relatives who are considering the facility as a care-giving option. The second manager, a man from Poland who for many years worked as an entrepreneur in the construction business in Germany, looks after the building. The care-giving staff of 'At the Riverside', as in the other facilities, are recruited from the facility's immediate vicinity.

The other facilities did not provide contact persons or addresses in Germany. With respect to the management team, 'At the Riverside' also differs from the other facilities, whose management team consisted of people from Poland with sometimes little or no knowledge of German and no living or working experiences in Germany. The facility 'At the Riverside' makes systematic use of its indicated alignment with and reference to the German context, by showing how they apply to other aspects of the facility as well.

\section{'The highest standards of care at an affordable price' - making low-cost care legitimate}

On its website, the facility proclaims that one of its key goals is 'offering the highest standards of care at an affordable price'. The prices listed are $€ 1,350$ for a singleoccupancy room and $€ 1,250$ for a double room - prices much lower than in Germany. The other facilities also pointed to their lower costs. In contrast to 
them, however, 'At the Riverside' links the lower prices to the highest standards of care. The reference to 'the highest standards of care' implicitly addresses the abovementioned assumption that low-cost care in Germany is linked to low quality of care and aims to counteract it. This is a first indication of the facility's reference to assumptions made about old-age care in Germany.

\section{Going abroad to prevent human and financial hardship}

This reference continues in the course of the interview, when the care manager develops another line of argument that serves to justify the financial considerations of relatives or potential care recipients when deciding on a placement in the facility. In this part of the interview, criticism of the care system and care policies in relation to older people in Germany comes into play. The care manager criticises the abovementioned regulations in Germany that can tap into or use up the personal property of people requiring care (e.g. their homes) or their children's income to make up for a cashflow shortfall in financing care. She points to the painstaking process of working for and buying a home of one's own in the course of a long working life, which in many cases, she says, goes along with the desire to ensure the wellbeing and financial protection of one's children. Moreover, she stresses that a long working life was spent paying into the state's social security fund. In her opinion, it takes so many years of work to save for and acquire a home, all the while also making social security contributions, that she regards seizing property or going after the children's income to cover care costs not only as unjust but, ultimately, as an inhuman practice. In effect, she implies that using people's homes to finance care symbolically signifies the destruction of their life achievement, which homeownership embodies.

This argument by 'At the Riverside' entails an empathetic siding with the relatives or potential care recipients by which the facility, represented by its care manager, positions itself as acting on behalf of their interests with respect to difficulties stemming from structural problems in care-giving and care policies in Germany. The facility can offer an economical alternative coupled with care that is not qualitatively inferior. This positions the facility as a humane actor offsetting the dismantling of care recipients' life achievements and the disadvantaging of their heirs. By accusing Germany's care policies of being the source of all the evil burdening the people needing care and their relatives, 'At the Riverside', as a potential alternative for mitigating these system-conditioned problems, practically becomes a 'knight in shining armour' or even a political actor. At the same time, the 'At the Riverside' management also counteracts possible arguments implying that choosing an old-age care facility in Poland for financial reason means 'taking the low road'. In this argument, using the facility instead becomes an option to prevent human hardship. This line of argument also shows that the facility is familiar with facts and discussions of old-age care in Germany - here in particular about the funding modalities of old-age care and the 'deportation discourse'. Based on this knowledge, it develops arguments which try to counter or pre-empt (potential) scepticism towards old-age care abroad.

The other facilities hardly made any comparable references to or attempts to refute doubts or fears in Germany associated with the use of care facilities in 
Poland at much cheaper prices. Although these facilities often knew that care in Germany is very expensive and poses a high burden on many, they did not make other references to the current criticism of old-age care facilities in Germany or to expectations about desirable care in Germany.

\section{The German infrastructure - feeling like at home}

The reference to Germany also becomes relevant with regard to the infrastructure of 'At the Riverside'. Right on the first page of the website, a reader reviewing the cost breakdown can see that the facility includes access to German radio and television. Moreover, during the interview the care manager points out that, in equipping the facility, management bought German tableware, intending to give residents a 'feeling of home'. This argument indicates that the facility links moving into or living in the facility to potential feelings of dislocation or unfamiliarity/ alienation induced by moving to a different country. 'Feeling of home' is linked to national origin.

Similarly, the German language is deemed to be an important criterion. On the website, the management introduces the facility as a 'German-speaking old-age care facility in Poland'; the staff's mostly good command of German is also emphasised. A German-language pastoral ministry available around the clock and a twiceweekly church service are also mentioned. The facility also taps into the historical background that led to the spread of the German language in the region where the facility is located and from where the staff are recruited. With the reminder that 'this of course used to be Germany', during the interview it is emphasised that the area's population grows up with German, due to having German-speaking grandparents or German language classes at school. These points not only reinforce the personnel's good knowledge of German, but the aforementioned pervasiveness of the German language also grounds the facility in a German-speaking environment. In comparison, arguments about the German language skills of the nursing staff were not mentioned in the other facilities, although some of them were also located in formerly German regions and some of their staff had good German language skills.

What is the significance of these 'German' references as symbolised by 'German materialities', the German language and German contact persons? Centrally, the facility takes up arguments which link a placement in an old-age care facility abroad to linguistic and/or cultural difficulties or alienation. These are the same arguments that were identified in the above-mentioned public opinion polls as pivotal reasons for rejecting care abroad. The example of tableware shows explicitly that with the orientation towards Germany, the facility intends to ensure familiarity and 'a feeling of home' and to counteract potential feelings of alienation resulting from living in another country. The facility intends to 'smooth out' differences between Germany and Poland. It insinuates that even though it is geographically located in Poland, several hundred kilometres away from the German-Polish border, its orientation is mainly 'German'. It is a 'German' facility in Poland, not a 'Polish' facility for people from Germany. With the German language, German tableware, German radio and television, and the German-speaking surroundings and contact persons, the facility projects an environment that minimises differences with Germany, intends 
to lessen fears of being uprooted and soothes potential anxieties regarding problematic verbal communications.

The other facilities barely address the fact that choosing a care facility abroad is linked to moving and living in another country, and when they do, they mostly addressed the issue of geographical distance. The distance, however, is relativised, for example by indicating that it can be overcome easily by car or train. Apart from the fact that the distances are by no means always easy to overcome, the example of the use of cars or trains shows that this argument is aimed at relatives or other persons who want to visit the residents. The perspective of the people in need of care and what it means for them to live in a facility abroad is not taken up.

\section{'German standards' - a quality feature of care}

In contrast to the other facilities, the reference to Germany is further taken up by 'At the Riverside' with regard to care delivery in the facility. Care provided by the facility and the professional qualifications of its staff are claimed to be comparable to 'German standards'. The reference to 'German standards' is prominently displayed on the website. As the website is an important medium for advertising and public relations, this indicates that these standards are considered a special mark of quality care. The fact that this reference is regarded both as necessary and important implies that the facility sees itself as (potentially) confronted with presumptions or fears that its level of care would not be aligned with expected quality standards; in other words, that it will offer relatively substandard care. Mentioning 'German standards' thus is an attempt to counter those assumptions proactively. In the interview, our interlocutor also points to the 'German standards' of care in the facility, stressing that 'it really is run like in Germany'.

When the interviewer asked the care manager what she means by 'German standards', she singled out care documentation. The reason for stressing the importance of documenting care is straightforward: should a resident apply for a higher level of care benefits from the German long-term care insurance, the corresponding German assessment organisation (German Medical Service) would conduct an on-site health assessment of this resident, and the facility's care documentation plays a crucial role in the decision-making process. The importance of care documentation thus results from Germany's administrative regulations, which are closely related to the facility's financing modality. As mentioned above, in addition to the residents' income (mostly pensions), the facility receives payments from the German long-term care insurance. In this way, good knowledge about the German context contributes to making the facility financially viable.

The second 'German standard' which is mentioned refers to the concept of activating care, which is presented in the interview as the key concept of the facility. This concept refers to the preservation of independence and competences of [older people in need of care], taking into account their resources and their mental, emotional and social concerns' (Hasseler et al., 2016: 51, translated by the authors). The German Social Security Act (Sozialgesetzbuch XI, 2017: section 11, para. 1) requires old-age care facilities in Germany to provide 'humane and activating care with due regard for human dignity' (translation by the authors). Moreover, the first report by the Federal Ministry for Family, Seniors, Women and Youth 
on old-age care facilities and care for residents pointed out specifically that activating care represents 'an essential attribute of quality care' (Bundesministerium für Familie, Senioren, Frauen und Jugend, 2006, translation by the authors). This indicates the high value placed on this concept of old-age care in Germany. Mentioning this concept during the interview thus reflects a self-positioning by the care manager, who, by aligning the facility with what is considered high-quality care in Germany, vouches for its own quality of care.

Given that the facility's care-givers are not trained in Germany, additional arguments are being developed to prevent possible scepticism about their qualifications. The care manager stresses that the staff's professional qualifications are comparable to or better than those of care-givers in Germany. Not only is it emphasised that employment in the facility requires professional qualifications; in the case of nurses, their competence is emphasised by detailing the length of their professional training in Poland. The interviewee stresses their good nursing skills repeatedly, along with the fact that nurses in Poland train two years longer than their German counterparts. She also reiterates their good command of the German language to counterbalance this possible shortcoming further. Last, but not least, reference is made to the facility's business model (see below) which allows staff to be highly qualified. In comparison with Poland's salary levels, she says, this model permits them to pay 'attractive wages', which is regarded as a prerequisite for being able to recruit 'highly qualified personnel'.

\section{Time as a 'Polish' resource and a corrective for German care conditions}

Given the strong criticisms levelled at old-age care facilities in Germany and the shortcomings outlined earlier, the facility's claims of care being 'just like in Germany' and being in line with 'German standards' as tokens of good care are surprising. Particularly puzzling are the references to care documentation and activating care as marks of high-quality care in Germany, considering that increasing 'bureaucratisation' of both practices is regularly criticised (Behr, 2015; Freifrau von Hirschberg and Kähler, 2015; Friesacher, 2015). Because of staffing shortages, meticulous documentation is often regarded as taking inordinate amounts of time away from working directly with the residents. In many cases, there is also not enough time to adhere to the principles of activating care. The care manager knows about these criticisms and argues that old-age care in Germany, dominated by recordkeeping, has turned into 'paper care' that leaves no time for activating care. Here again, statements are taken up that characterise the discussions about old-age care in Germany.

This is where a specific resource comes into play for the facility: disposing of more time thanks to a 'very good' staffing ratio becomes the crucial corrective. The interviewee calls German staffing level ratios ranging from 1:10 to 1:15 'abysmal' and 'off the chart', and characterises them as making care-givers constantly, unacceptably pressed for time, leaving them scarcely able to provide adequate care. This would also reflect her own experiences as a geriatric nurse in Germany. 'At the Riverside', in contrast, has a 'very good staff ratio' (1:5 to 1:6). Thus, the commensurate 'big difference' from Germany consists in 'simply [having] time'. According to the interviewee, having enough time constitutes the central 
difference between care at the facility and care at facilities in Germany, where caregiving staff are rushed off their feet and constantly preoccupied with thinking of 'everything that remains to be done'. 'Having time' turns out to be a special seal of quality - a line of argument which is also often cited in Germany (e.g. Schweiger, 2011: 88). For the interviewee, this is attested by many of the residents who, she says, perk up and gain new vitality and joie de vivre. She claims that staff members have enough time to pay individual attention, as well as to show 'affection' and 'love', all qualities she identifies as being key to good care. Statements in the interview that 'many who come to us in a really poor state ... [ find a new lease on life]' aim to testify to the quality of care delivered in the facility.

A reduction in the use of sedatives is identified as another result of the facility's quality of care. This is considered an important reason for people 'perking up'. As an example, the care manager refers to a woman who came 'drugged' and bedridden from Germany to live at the facility. With the diminished use of tranquilisers, she was able to begin using a rolling walker and her previously aggressive behaviour was markedly reduced. Here, too, another criticism levelled at German old-age care facilities is addressed. As mentioned above, in Germany, the topic of immobilising people with medication is repeatedly covered by the media. Since the pervasiveness of the practice of sedation in German care facilities is considered a consequence of a lack of time on the part of care-givers (e.g. Gröning and Lietzau, 2010), here once more the good staffing ratio in the facility in Poland proves to be a special resource.

To sum up, the argument unfolds as follows: the care principles in Germany are good, but due to insufficient time resources, i.e. staffing shortages, they cannot be realised. Changing the time factor, i.e. having more or sufficient personnel available, enables an old-age care facility to be aligned with Germany's (supposedly) good care principles and provision, and to provide a high quality of care and quality of life. Concealed in this argumentation is the fact that the better staffing ratio and hence the freed-up time are made possible by the facility's business model. The facility benefits from the differences in salary and cost of living between Germany and Poland in two ways. First, the difference enables the facility's lower costs compared to Germany. Second, by marketing itself to people from Germany (and not Poland), the reasonable price is pegged to the incomes of pensioners from Germany, who experience a gain in purchasing power in Poland and thus create the latitude for employing sufficient staff.

\section{Good working conditions for Polish care-givers and economic development for the region}

Conceivably, taking advantage of differences in pay and living costs might attract criticism, especially with regard to accusations of exploitation due to the fact that the non-affordable care in Germany is shifted to lower-wage countries, thus 'solving' Germany's costs burdens by exploiting global wage differences. But the facility is ready to address this objection, too, highlighting the 'attractive salaries' that are made possible because of the above-mentioned business model. In addition, lack of time and being rushed are related to the working conditions of care-givers in Germany and described as 'abysmal' and unreasonable earlier on in the interview. They are said to result in considerable mental stress or even staff 'burnout'. 
Conversely, care-giver jobs in the 'At the Riverside' facility, with their reduced workloads and improved working conditions (compared with Germany's), are presented as better and less stressful. In addition, the attractiveness of working in the facility is enhanced by the absence of an assumed commute between Poland and Germany. The reference here is to the widespread practice of private households in Germany hiring Polish care workers. According to this argument, having job opportunities locally thus eliminates the need for workers to deal with difficult commutes. Moreover, local jobs not only benefit the workers, but are also linked to development in the region: by creating jobs in the area, as stated on the website, the facility simultaneously helps boost the area's (poor) economy.

\section{Making 'At the Riverside' a legitimate option for old-age care for people from Germany}

To summarise, 'At the Riverside' presents itself as a facility that combines low costs with a high quality of care. It not only levels out the differences between Germany and Poland by orienting itself to Germany in regard to its equipment, language and care, but also offers a better care quality compared to Germany. Taking advantage of the more favourable salaries and living costs in Poland is simultaneously qualified as a humane and politically correct action that goes hand in hand with good working conditions for the Polish care-givers and promotion of the region's economic development. In order for the facility to position itself accordingly, three lines of argument are of particular importance: reasonable costs, the foreign country and the business model.

\section{Reasonable costs}

Against the background of low-priced old-age care facilities being associated with substandard care in Germany, 'At the Riverside' develops an argument which counters this scepticism by referring to its high quality of care. The sometimes sharp criticism which associates the use of old facilities in Poland for financial reasons with the discourse about 'deporting' older people is also counterbalanced. Based on an argument which describes the financial regulations of German care policy as unreasonable and inhumane, the use of 'At the Riverside' is presented as a humane alternative that prevents human suffering.

\section{The foreign country (Poland)}

This refers to fears in Germany that link placing a person in an old-age care facility abroad to language difficulties, difficulties of orientation or a loss of medical care standards. The facility counters these markers of difference by referring to the use of German language and German care standards. This serves to balance out differences and to liken the facility to Germany in material and cultural (language) terms. With respect to care, however, the facility not only counters the idea of potentially lower quality, which Germans sometimes link to homes abroad. In effect, the facility promises a higher quality of care compared to Germany. By virtue of having sufficient personnel, it claims to overcome the limitations and problems 
of care caused by staff shortages in Germany. The recourse to Polish workers is necessary to make delivering the kind of care that is regarded as good care in Germany feasible.

\section{The business model}

As the business model might provoke criticism of the exploitation of staff and differences in the cost of living, references to providing good working conditions and creating jobs in the area serve as rebuttals in this context. The facility positions itself as a good employer and development actor which creates alternatives to onerous commuting jobs and furthers the economic development of an area known to be impoverished.

It is these lines of arguments that are of particular relevance with regard to its positioning as a legitimate option of old-age care for people from Germany. Above we pointed out that a crucial element of legitimacy is reflected by 'a generalized perception or assumption of an organization's accordance with socially constructed systems of norms, values, beliefs or definitions' (Suchman, cited in Walgenbach and Meyer, 2008: 64). Since the facilities target the German market and if they want to secure their existence through demand from people in Germany, old people in need of care in Germany and their relatives can be regarded as an essential reference group for this facility, with whom accordance has to be established. The example of 'At the Riverside' shows how it takes on this challenge in a specific way.

An essential feature of the line of argument used by 'At the Riverside' is its (sometimes implicit) reference to the structures, practice and public discourses of old-age care facilities in Germany as well as to the reasons for scepticism of people in Germany towards placing a person in a care facility abroad. It projects itself as a facility that provides arguments for minimising doubts about placements abroad and counteracts the problems of old-age care facilities in Germany. The promises of high-quality care, with enough time to give individual attention to the clients and maintaining a familiar environment are at the core of it. It positions itself as a facility which is guided by the motto 'Just like in Germany, only better'. Ultimately, it puts itself forward as a facility which allows 'German' standards of care to reach their full potential. Hereby, it presents itself as a facility which takes up the expectations of a desirable old-age care in Germany which implicitly emerge from the above-mentioned criticisms of old-age care facilities in Germany and the reasons for rejecting care abroad.

In this regard, the knowledge of the facility about the German old-age care system and its criticisms is an important element. The reference to old-age care facilities in Germany - explicitly (interview) and implicitly (website) - runs through like a thread in the facility's self-presentation. Through this knowledge it is possible to build on both the problems and the expectations of desirable care in Germany. In this respect, the composition of the management team with people who have lived in Germany and have a long-standing professional experience in old-age care in Germany seems to be a smart move. Especially, the interview with the care manager shows how she ties her arguments repeatedly to her own professional experience in Germany.

'At the Riverside' significantly differs from the other facilities, which position themselves as advantageous as compared to Germany primarily because of their 
lower costs. The low take-up shows, however, that low prices alone do not attract a substantial number of residents into the facilities. By offering lower costs they do address a severe problem of old-age care facilities in Germany. However, other references to care in Germany are barely addressed or are ignored. Above all, they do not take up or refute the arguments that reject the use of a care facility abroad due to linguistic or cultural differences, fears of alienation or which associate poor quality with care abroad. Compared to 'At the Riverside', which projects itself by its motto 'Just like in Germany, only better', these facilities rather position themselves as 'low-cost facilities for people from Germany'.

\section{Discussion and conclusion}

It is this very difference which is important for questions of legitimacy. Against the backdrop that legitimacy is always linked to a specific field or reference group and the fact that care facilities in Poland aim at the market in Germany, the challenge for these facilities consists of being able to position themselves vis-à-vis Germany and especially people in need of care from Germany and their relatives in such a way that the question of their use can be answered with 'yes, this the right thing to do'. Also, if this answer depends on 'whether the activity effectively promotes societal welfare, as defined by the audience's socially construed value system' (Suchman, 1995: 579), in the case of 'At the Riverside' this challenge seems to be better met than the other facilities which primarily highlight lower prices. Even though they respond to the cost burden in Germany, they hardly project perspectives of a better quality of care. Against the background of fears that lower-cost care may come at the expense of quality of care, and of the reproachful discourse of deporting older people abroad for cost reasons, the facilities fall into the trap of a motive which does not connect to 'the audience's socially construed value system' about old-age care in Germany.

To summarise, we examined the legitimation strategies used by these facilities based on their self-presentation. In this regard, 'At the Riverside' projects itself as a more promising option than other facilities. However, an immediate question may arise: 'Does it really hold up to its promises?' This question is insightful and immediately leads to further research perspectives in which the experiences of the residents, their relatives and the staff need to be taken into account in order to answer the question of whether and under which circumstances old-age care facilities abroad can be considered as an alternative to the problem-ridden residential old-age care in Germany.

Acknowledgements. We would like to thank the reviewers for their very insightful comments, as well as Manuela Popovici for her excellent proof-reading and her very instructive comments.

\section{NOTES}

1 The Bundesverband privater Anbieter sozialer Dienste (2012) estimated a gap of around 30,000 care workers in Germany in 2012. For 2030, this gap is projected to almost half a million (Bertelsmann Stiftung, 2012).

2 For reasons of anonymity we do not include the website's address. 


\section{References}

Arend S (2017) Sorge(n)volle Zustände. In Arend S and Klie T (eds), Wer pflegt Deutschland. Transnationale Pflegekräfte-Analysen, Erfahrungen, Konzept. Hannover, Germany: Vincentz Network, pp. 11-30.

Behr T (ed.) (2015) Aufbruch Pflege. Hintergründe - Analysen - Entwicklungsperspektiven. Wiesbaden, Germany: Springer.

Bender D, Hollstein T and Schweppe C (2017) The emergence of care facilities in Thailand for older German-speaking people: structural backgrounds and facility operators as transnational actors. European Journal of Ageing 14, 365-374.

Bertelsmann Stiftung (2012) Themenreport 'Pflege 2030'. Was ist zu erwarten - was ist zu tun? Bielefeld, Germany: Matthiesen Druck.

Bundesministerium für Familie, Senioren, Frauen und Jugend (2006) Erster Bericht des Bundesministeriums für Familie, Senioren, Frauen und Jugend über die Situation der Heime und die Betreuung der Bewohnerinnen und Bewohner. Berlin: Bundesministerium für Familie, Senioren, Frauen und Jugend.

Bundesverband privater Anbieter sozialer Dienste (2012) Zehntausende Pflegefachkräfte fehlen und die Arbeitsagentur streitet mit den Ländern. Available at http://www.bpa.de/Aktuelles.112.0.html?\&no_cache $=1 \&$ tx_ttnews\%5Btt_news\%5D=502\&cHash=f07251b690e83a999f64fdbca75cf00f.

Engelmann D, Gohde J, Künzel G and Schmidt S (2013) Gute Pflege vor Ort. Das Recht auf eigenständiges Leben im Alter. Bonn: Friedrich-Ebert-Stiftung.

European Union (2009) Consolidated Versions of the Treaty on the European Union and the Treaty on the Functioning of the European Union. Luxembourg: Publications Office of the European Union.

Focus Online (2012) Billig-Pflege in Osteuropa und Asien. Die Deutschen schicken ihre Alten und Kranken ins Ausland. Focus Online, December 28. Available at http://www.focus.de/politik/deutschland/tid-28774.

Focus Online (2014) Der 'Oma-Export'. So schiebt Deutschland seine Alten nach Osteuropa ab. Focus Online, October, 25. Available at http://www.focus.de/gesundheit/videos/der-oma-export-so-schiebtdeutschland-seine-alten-nach-osteuropa-ab_id_4225677.html.

Freifrau von Hirschberg K-R and Kähler B (2015) Positionspapier: Psychische Belastungen in der Pflege und die Rolle der Pflegedokumentation. In Behr $\mathrm{T}$ (ed.), Aufbruch Pflege. Hintergründe Analysen - Entwicklungsperspektiven. Wiesbaden, Germany: Springer, pp. 163-186.

Friesacher H (2015) Wider die Abwertung eigentlicher Pflege. intensiv 15, 200-213.

Grassberger M and Püschel K (eds) (2013) Forensische Gerontologie: Gewalt gegen alte Menschen. Wiesbaden, Germany: Springer.

Gröning K and Lietzau Y (2010) Gewalt gegen ältere Menschen. In Aner A and Karl U (eds), Handbuch Soziale Arbeit und Alter. Wiesbaden, Germany: Springer, pp. 361-367.

Hasseler M, Stemmer R, Macsenaere M, Arnold J and Weidekamp-Maicher M (2016) Abschlussbericht. Entwicklung eines wissenschaftlich basierten Qualitätsverständnisses für die Pflege- und Lebensqualität. Available at https://www.gkv-spitzenverband.de/media/dokumente/pflegeversicherung/qualitaet_in_der_ pflege/wiss_qualitaetsverstaendnis/2016-08-25_Abschlussbericht_wiss_Qualitaetsverstaendnis.pdf.

Horn V, Schweppe C, Bender D and Hollstein T (2016) 'Moving (for) elder care abroad': the fragile promises of old age care facilities for elderly Germans in Thailand. In Horn V and Schweppe C (eds), Transnational Aging. Current Insights and Future Challenges. New York, NY: Routledge, pp. 163-177.

Kahlweit C (2016) Wenn die Rentner in den Osten ziehen. Süddeutsche Zeitung, August 14. Available at http://www.sueddeutsche.de/wirtschaft/report-zuhause-am-plattensee-1.3118855.

Konpress and Emnid (2013) Pflege im Ausland - im Alter ins Exil? Available at http://konpress.de/wpcontent/uploads/Emnid-Repr\%C3\%A4sentativbefragung-Pflege-im-Ausland-final.pdf.

Kunze A (2015) Wider Willen ruhig gestellt. Die Zeit Online, July 24. Available at http://www.zeit.de/2015/ 30/pflegeheim-medikamente-beruhigungsmittel.

Lipszy B, Sail E and Xavier A (2012) European Economy. Long-term Care: Need, Use and Expenditure in the EU-27. Directorate-General for Economic and Financial Affairs, Brussels, Economic Paper 469.

Mihm A (2013) Kein 'Oma-Export' nach Osteuropa: Der Deutsche lässt nur ungern im Ausland pflegen. Frankfurter Allgemeine Zeitung, January 21. Available at http://www.faz.net/aktuell/wirtschaft/men schen-wirtschaft/kein-oma-export-nach-osteuropa-der-deutsche-laesst-nur-ungern-im-ausland-pflegen12031697.html. 
Mischke C, Koppitz AL, Dreizler J and Händler-Schuster D (2015) Eintritt ins Pflegeheim: Das Erleben der Entscheidung aus der Perspektive der Pflegeheimbewohnerinnen und Pflegeheimbewohner. Journal für Qualitative Forschung in Pflege- und Gesundheitswissenschaft 2, 72-81.

Posener A (2014) Deutschland wird Weltmeister im Oma-Export. Die Welt, October 24. Available at https://www.welt.de/kultur/article133590183/Deutschland-wird-Weltmeister-im-Oma-Export.html.

Prantl H (2012) Die verrückte Idee vom Greisen-Export. Süddeutsche Zeitung, February 11. Available at http://www.sueddeutsche.de/politik/pflegeheime-im-ausland-die-verrueckte-idee-vom-greisen-export-1. 1512615.

Schneekloth U and Wahl H-W (2009) Pflegebedarf und Versorgungssituation bei älteren Menschen in Heimen. Demenz, Angehörige und Freiwillige, Beispiele für 'Good Practice'. Stuttgart, Germany: Kohlhammer.

Schweiger P (2011) 'Wir haben zwar Geduld, aber keine Zeit'. Eine Ethnografie subjektivierter Arbeitsstile in der ökonomisierten Altenpflege. München, Germany: Herbert Utz Verlag.

Sozialgesetzbuch XI (2017) Das gesamte Sozialgesetzbuch SGB I bis SGB XII. Regensburg, Germany: Walhalla Verlag.

Statistisches Bundesamt (2015) 20 Jahre Pflegeversicherung: Immer mehr auf Hilfe zur Pflege angewiesen. Available at https://www.destatis.de/DE/ZahlenFakten/ImFokus/Soziales/PflegebeduerftigeSozialhilfe. html.

Statistisches Bundesamt (2017) Pflegestatistik 2015. Pflege im Rahmen der Pflegeversicherung Ländervergleich-Pflegeheime. Available at https://www.destatis.de/DE/Publikationen/Thematisch/ Gesundheit/Pflege/PflegeDeutschlandergebnisse5224001159004.pdf?__blob=publicationFile.

Strauss AL and Corbin JM (1996) Grounded Theory: Grundlagen qualitativer Sozialforschung. Weinheim, Germany: Beltz.

Suchman MC (1995) Managing legitimacy: strategic and institutional approaches. Academy of Management Journal 20, 571-610.

Toyota M and Thang LL (2017) Transnational retirement mobility as processes of identity negotiation: the case of Japanese in South-east Asia. Identities 24, 557-572.

Toyota M and Xiang B (2012) The emerging transnational 'retirement industry' in Southeast Asia. International Journal of Sociology and Social Policy 32, 708-719.

Walgenbach P and Meyer R (2008) Neoinstitutionalistische Organisationstheorie. Stuttgart, Germany: Kohlhammer.

Westfälische Nachrichten (2012) Empörung über 'Oma-Export'. Demenzkranke werden in Pflegeheime ins Ausland 'verschoben'. Westfälische Nachrichten, November 23. Available at http://www.wn.de/NRW/2012/ 11/Empoerung-ueber-Oma-Export-Demenzkranke-werden-in-Pflegeheime-ins-Ausland-verschoben.

Cite this article: Großmann S, Schweppe C (2020). Just like in Germany, only better? Old-age care facilities in Poland for people from Germany and the question of legitimacy. Ageing \& Society 40, 823-841. https:// doi.org/10.1017/S0144686X18001290 